\title{
The Associations of Clean and Healthy Behavior, Social Capital, and Nutritional Status in Children Under Five in Waingapu Health Center
}

\author{
Stevani Rambu Kudu'), Yulia Lanti Retno Dewi²), Setyo Sri Raharjo²) \\ ${ }^{1)}$ Masters Program of Public Health, Universitas Sebelas Maret \\ 2)Faculty of Medicine, Universitas Sebelas Maret
}

\section{ABSTRACT}

Background: Quality nutrition is a determinant of children's survival, health, and growth. Nutritional problems and lack of nutrient intake are also about whether bad in the environment or commonly known as clean and healthy behavior. Social capital refers to social relationships and connections between individuals because it is more of a relationship between individuals than an individual attribute. This study aimed to examine the relationship between clean and healthy behavior and social capital with the nutritional status of children under five at the Waingapu City Health Center.

Subjects and Method: This was a crosssectional study conducted at the Waingapu Health Center, East Sumba, East Nusa Tenggara, Indonesia, in April 2021. The sample was 200 mothers, and children under five were selected randomly. The dependent variable was child nutritional status (WAZ). The independent variables were social capital, clean and healthy behavior, gender, maternal age, maternal occupation, and maternal education. Data were collected by using a questionnaire and analyzed by multiple logistic regression.

Results: Clean and healthy lifestyle improved good nutritional status $(\mathrm{OR}=5.50 ; 95 \% \mathrm{CI}=$ 1.19 to 25.43 ; $p=0.029$ ). High social capital increased good nutritional status $(\mathrm{OR}=2.28 ; 95 \%$ $\mathrm{CI}=1.15$ to $4.51 ; \mathrm{p}=0.017$ ).

Conclusion: Healthy, clean living behavior, and high social capital improve good nutriational status.

Keywords: clean and healthy behavior, social capital, nutritional status

\section{Correspondence:}

Stevani Rambu Kudu. Masters Program in Public Health, Universitas Sebelas Maret. Jl. Ir. Sutami 36A, Surakarta 57126, Central Java. Email: Stevaniro9@student.uns.ac.id. Mobile: 082226431161.

Cite this as:

Kudu SR, Dewi YLR, Raharjo SS (2021). The Associations of Clean and Healthy Behavior, Social Capital, and Nutritional Status in Children Under Five in Waingapu Health Center. J Health Promote Behav. 06(01): 5766. https://doi.org/10.26911/thejhpb.2021.06.01.06.

(c) (i) Journal of Health Promotion and Behavioris licensed under a Creative Commons

Attribution-NonCommercial-ShareAlike 4.o International License.

\section{BACKGROUND}

Quality nutrition is a determinant of the survival, health, and growth of children. Well-nourished children can grow and learn, participate and benefit society, and survive the challenges of disease, natural disasters, and other forms of global crises. Therefore, child nutrition is also a key priority in Indonesia and part of the government's commitment to Sustainable Development Goals (SDGs) to tackle nutritional problems such as low birth weight and stunting (Unicef, 2020).

Most forms of malnutrition in all parts of the world, from rural to urban, are rooted in poverty and injustice. Children living in extreme poverty in low-income countries, especially in remote areas, are more likely to be underweight and malnourished. They do not have access to clean water, sanitation, and health care (Unicef, 2019). 
Malnutrition in children under five is still a fundamental problem in the world. It was estimated that $34 \%$ of under-five deaths are caused by malnutrition (WHO, 2013). Moreover, the age of children under five years is a stage of development of children susceptible to disease, including diseases caused by lack or excess nutriational intake (Unicef, 2012).

Malnutrition and malnutrition are the statuses of a person's condition who lacks nutrition or below average. Malnutrition is a lack of nutritional ingredients such as protein, carbohydrates, fats, and vitamins needed by the body (Krinansari, 2010). The prevalence of malnutrition and undernutrition among children under five in Indonesia is $3.9 \%$ under five with severe malnutrition and $13.8 \%$ under five with malnutrition (Riskesdas, 2018).

Many factors influence the occurrence of malnutrition in toddlers, and some of the direct causes are lack of food intake and the presence of infectious diseases. However, these causes are always accompanied by other, more complex backgrounds such as social and economic conditions, education level, environmental conditions, and parenting given to toddlers (Hidayat, 2010).

The prevalence of malnutrition and undernutrition among children under five in Indonesia is $3.9 \%$ under five with severe malnutrition and $13.8 \%$ under five with malnutrition (Riskesdas, 2018). Nutritional problems and lack of nutrient intake are also about whether bad in the environment or commonly known as clean, healthy behavior (Supraptini, 2011). Healthy environmental sanitation indirectly affected the health of children under five, which can affect the nutritional status of children under five (Hidayat, 2011).

Behavior affects individual health to foster and improve public health interventions aimed at these behavioral factors are very strategic. Healthy clean living behavior is all health behaviors carried out because of personal awareness. Families and all members can help themselves in the health sector and have an active role in community activities (Kemenkes, 2016). Social capital refers to social relationships and connections between individuals because it is more a relationship between individuals than an individual attribute. The key concept here is that social capital is not an individual characteristic or personality trait but a resource that lies and groups of people. These resources are useful for health production if utilized (Murti, 2009).

In Indonesia, with forms of social relations in mutual assistance, a sense of kinship, and a high sense of togetherness, it is possible to develop social capital. Assistance is provided by the local community and support from the social environment to support toddlers' nutritional status (Runingsari, 2014).

East Nusa Tenggara (NTT) is one of the provinces in Indonesia with a high prevalence of malnutrition. The prevalence of malnutrition in East Nusa Tenggara, including East Sumba Regency in children under five based on weight indicators by age in 2018, was 29.5\% (Riskesdas, 2018). The results of recording and reporting on community-based nutrition in August 2020 at the Waingapu City Health Center were 89 underweight children (East Sumba Health Office, 2020). This study aimed to examine the relation $\neg$ ship between clean and healthy behavior and social capital with the nutritional status of children under five at the Waingapu City Health Center.

\section{SUBJECTS AND METHOD}

\section{Study Design}

This was an analytic observational study with a cross-sectional design. The study was conducted at the Waingapu Health 
Kudu et al./ Clean and Healthy Behavior, Social Capital, and Nutritional Status

Center, East Sumba, East Nusa Tenggara, Indonesia, in April 2021.

\section{Population and Sample}

The study population consisted of all mothers who had children under five. In addition, a sample of 200 mothers who had children aged under five was selected randomly.

\section{Inclusion Criteria}

Mothers who had children aged 12-60 months, live in the Waingapu Health Center, and were willing to be research subjects.

\section{Exclusion Criteria}

The exclusion criteria were children who did not live with their parents, children with physical disabilities.

\section{Study Variables}

The dependent variable was child nutritional status. The independent variables were social capital, gender, maternal age, maternal education, and maternal occupation.

\section{Operational Definition of Variable}

Social capital is the characteristics of social organizations, such as networks, norms, and social trust, facilitating coordination and cooperation for mutual benefit (Putnam, 2000).

Child nutritional status is the nutritional status of toddlers, which is using the indicator of weight for age (Bodyweight/Age) in kilograms (kg).

Clean and healthy behavior is a family practice or behavior related to the maintenance and improvement of environmental health in household arrangements in the Waingapu Health Center. It was measured by 10 clean and healthy behavior indicator questions.

Maternal age is the age in years calculated based on the birth certificate or proof.

Maternal education is the last level of formal education completed by the mother.

Maternal occupation is the mother's livelihood to earn income outside the home. Child's gender is a biological characterristic seen from the outward appearance of children.

\section{Study Instrument}

Children's body weight was measured by weight scale. The other variables were collected by questionnaire.

\section{Data Analysis}

The data in this study were analyzed using multiple logistic regression.

\section{RESULTS}

\section{A. Overview of Research Locations}

Waingapu City Health Center is the only health center in Waingapu City District. Waingapu City Health Center was located in an urban area, precisely in the capital of East Sumba Regency. Waingapu Health Center is located in the vicinity of residential areas and the city center. Waingapu Health Center had an area of 73.8. There is 1 village located outside Waingapu City, namely Mbatakapidu village, which is located quite far from the health center.

\section{B. Univariate Analysis}

Table 1. Frequency distribution of research variables with continuous data

\begin{tabular}{lccccc}
\hline Variable & n & Mean & SD & Minimum & Maximum \\
\hline Maternal age (year) & 200 & 31.52 & 5.59 & 19 & 48 \\
Clean and Healthy Behavior & 200 & 8.96 & 1.02 & 5 & 10 \\
Social Capital & 200 & 59.15 & 4.26 & 44 & 63 \\
\hline
\end{tabular}

Table 1 showed that the average age of mothers under five was 31.52 years, the average clean and healthy behavior was
8.96, and the average social capital of mothers was 59.15 . 
Kudu et al./ Clean and Healthy Behavior, Social Capital, and Nutritional Status

\section{C.Subjects Characteristics}

\section{Table 2 Characteristics of research subjects}

\begin{tabular}{lcc}
\hline \multicolumn{1}{c}{ Characteristics } & n & \% \\
\hline Maternal Age & & 74.50 \\
20-30 year & 149 & 25.50 \\
>35 year & 51 & 36 \\
Maternal Education & & 64 \\
None/PS/JHS & 72 & 36.50 \\
SHS/College/Academy & 128 & 63.50 \\
Gender & & \\
Male & 73 & \\
Female & 127 & \\
\hline
\end{tabular}

Table 3. Frequency distribution of research variables with categorical data

\begin{tabular}{lcc}
\hline Variable & $\mathbf{n}$ & \% \\
\hline PHBS & 192 & 96 \\
Good & 8 & 4 \\
Poor & & \\
Social Capital & 90 & 55 \\
Low & 110 & 55 \\
High & & 36 \\
Maternal Education & 72 & 64 \\
None/PS/JHS & 128 & 74.50 \\
SHS/College/Academy & & 25.50 \\
Maternal Age & 149 & 85.50 \\
2O-35 year & 51 & 14.50 \\
>35 year & & \\
Maternal Occupation & 171 & 36.50 \\
Housewife & 29 & 63.50 \\
Working mom & & \\
Toddlers' Gender & 73 & 72 \\
Male & 127 & 28 \\
Female & & \\
Toddlers' Nutritional Status & 171 & 29 \\
Normal & 29 & \\
Not Normal & & \\
\hline
\end{tabular}

The results of the frequency distribution of the characteristics of study subjects based on Table 2 showed that most of the mothers aged 20-35 years were 149 subjects (74.50\%). The characteristics of the study subjects based on the level of education showed that most of the education levels of mothers graduated from high school/ college/ academy with 128 subjects (64\%). Characteristics of study subjects by gender, most of them were female 127 subjects (63.50\%).
Table 3 showed the clean and healthy behavior of the households, mostly the clean and healthy behavior in the good category as much as $96 \%$. Mother's social capital was mostly high social capital as much as $55 \%$, child's gender was $63.50 \%$ female, mother's education was >high school as much as $64 \%$, mother's age was 20-35 years as much as 74.50, mother's occupation was some housewives as much as $85.50 \%$, most of the nutritional status was normal as much as $72 \%$. 
Kudu et al./ Clean and Healthy Behavior, Social Capital, and Nutritional Status

\section{D.Bivariate Analysis}

Table 4. The results of the chi-square test between nutritional status (WAZ) and clean, healthy living behavior, social capital, gender of toddlers, mother's education, mother's age, mother's occupation

\begin{tabular}{|c|c|c|c|c|c|c|c|c|c|}
\hline \multirow[t]{3}{*}{ Variable } & \multicolumn{5}{|c|}{ Nutritional Status } & \multicolumn{2}{|c|}{ CI $95 \%$} & \multirow{3}{*}{ OR } & \multirow{3}{*}{$\mathbf{p}$} \\
\hline & \multicolumn{2}{|c|}{ Normal } & \multicolumn{3}{|c|}{ Not Normal } & \multirow{2}{*}{$\begin{array}{l}\text { Lower } \\
\text { Limit }\end{array}$} & \multirow{2}{*}{$\begin{array}{l}\text { Upper } \\
\text { Limit }\end{array}$} & & \\
\hline & $\mathbf{n}$ & $\%$ & n & $\%$ & $\%$ & & & & \\
\hline \multicolumn{10}{|l|}{ 1. Clean and } \\
\hline healthy & 3 & 37.50 & 5 & 62.50 & 100 & 0.85 & 30.45 & 4.60 & 0.027 \\
\hline behavior & 141 & 73.44 & 51 & 26.56 & 100 & & & & \\
\hline Poor & & & & & & & & & \\
\hline Good & & & & & & & & & \\
\hline \multicolumn{10}{|l|}{ 2. Social Capital } \\
\hline Low & 55 & 61.11 & 35 & 38.89 & 100 & 1.36 & 5.83 & 2.69 & 0.002 \\
\hline High & 89 & 80.91 & 21 & 19.09 & 100 & & & & \\
\hline \multicolumn{10}{|l|}{ 3. Maternal } \\
\hline $\begin{array}{l}\text { Education } \\
\text { None/PS/JHS }\end{array}$ & 42 & 58.33 & 30 & 41.67 & 100 & 1.41 & $5 \cdot 56$ & 2.80 & 0.001 \\
\hline $\begin{array}{l}\text { SHS/College/ } \\
\text { Academy }\end{array}$ & 102 & 79.69 & 26 & 20.31 & 100 & & & & \\
\hline \multicolumn{10}{|l|}{ 4. Gender } \\
\hline Male & 54 & 73.97 & 19 & 26.03 & 100 & 0.42 & 1.70 & 0.85 & 0.638 \\
\hline Female & 90 & 70.87 & 37 & 29.13 & 100 & & & & \\
\hline \multicolumn{10}{|l|}{ 5. Maternal Age } \\
\hline 20-35 year & 109 & 73.15 & 40 & 26.85 & 100 & 0.38 & 1.73 & 0.80 & 0.534 \\
\hline$>35$ year & 35 & 68.63 & 16 & 31.37 & 100 & & & & \\
\hline \multicolumn{10}{|l|}{$\begin{array}{l}\text { 6. Maternal } \\
\text { occupation }\end{array}$} \\
\hline Housewife & 122 & 71.35 & 49 & 28.65 & 100 & 0.26 & 2.08 & 0.79 & 0.616 \\
\hline Working mom & 22 & 75.86 & 7 & 24.14 & 100 & & & & \\
\hline
\end{tabular}

There was a positive relationship between healthy hygiene and nutritional status, and it was statistically significant. Children under five from mothers who had good clean and healthy behavior could have a good nutritional status of 4.60 times than poor clean and healthy behavior $(\mathrm{OR}=$ 4.60; $95 \% \mathrm{CI}=0.85$ to $30.45 ; \mathrm{p}=0.027$ ).

Social capital and nutritional status had a positive relationship, and it was statistically significant. Children under five from mothers with high social capital had a 2.69 times probability of good nutritional status than mothers with low social capital $(\mathrm{OR}=2.69 ; 95 \% \mathrm{CI}=1.36$ to $5.83 ; \mathrm{p}=$ 0.002).
Education and nutritional status had a positive relationship, and it was statistically significant. Children who had a mother with higher education had the probability of having good nutritional status 2.80 times than those who had a mother with low education $(\mathrm{OR}=2.80$; $95 \% \mathrm{CI}=$ 1.41 to $5.56 ; p=0.001$ ).

There was no difference of nutritional status between male and female $(\mathrm{OR}=0.85$; $95 \% \mathrm{CI}=0.42$ to $1.70 ; \mathrm{p}=0.638)$, maternal age $(\mathrm{OR}=0.80 ; 95 \% \mathrm{CI}=0.38$ to $1.73 ; \mathrm{p}=$ 0.534), and maternal occupation ( $\mathrm{OR}=$ o.79; CI 95\%=0.26 to 2.08; $\mathrm{p}=0.616$ ). 
Kudu et al./ Clean and Healthy Behavior, Social Capital, and Nutritional Status

\section{E. Multivariate Analysis}

Table 5. Results of multiple logistic regression of the relationship between clean and healthy living behavior, social capital, and nutritional status (WAZ)

\begin{tabular}{|c|c|c|c|c|}
\hline \multirow[t]{2}{*}{ Independent variable } & \multirow[t]{2}{*}{ OR } & \multicolumn{2}{|c|}{$95 \% \mathrm{CI}$} & \multirow[t]{2}{*}{$\mathbf{p}$} \\
\hline & & Lower Limit & Upper Limit & \\
\hline PHBS (High) & 5.50 & 1.19 & 25.43 & 0.029 \\
\hline Social Capital (High) & 2.28 & 1.15 & 4.51 & 0.017 \\
\hline Age $(\geq 35$ year $)$ & 1.01 & 0.47 & 2.15 & 0.977 \\
\hline Education $((\geq \mathrm{SHS})$ & 2.49 & 1.27 & 4.89 & 0.008 \\
\hline Occupation (Working outside) & 1.23 & 0.47 & 3.23 & 0.666 \\
\hline Gender (Female) & 0.86 & 0.43 & 1.72 & 0.676 \\
\hline \multicolumn{5}{|l|}{$\mathrm{N}$ observation $=200$} \\
\hline \multicolumn{5}{|l|}{ Loglikehood=-107.79 } \\
\hline $\mathrm{p}=0.001$ & & & & \\
\hline
\end{tabular}

Table 5. presented the results of multiple logistic regression analysis of the relationship between clean and healthy living behavior and social capital with the nutritional status of children under five. There was a positive relationship between healthy hygiene and nutritional status, and it was statistically significant. Children under five from mothers who had good clean and healthy behavior had a 5.50 times probability of good nutritional status than poor clean and healthy behavior (OR 5.50; 95\% $\mathrm{CI}=1.19$ to $25.43 ; \mathrm{p}=0.029$ )

Social capital and nutritional status had a positive relationship, and it was statistically significant. Children under five from mothers with high social capital had a 2.28 times probability of good nutritional status than mothers with low social capital $(\mathrm{OR}=2.28 ; 95 \% \mathrm{CI}=1.15$ to $4.51 ; \mathrm{p}=0.017)$.

Education and nutritional status had a positive relationship, and it was statistically signifycant. Children under five of mothers with higher education had the probability of having good nutritional status 2.49 times than mothers with low education $(\mathrm{OR}=2.49 ; 95 \% \mathrm{CI}=1.27$ to 4.89 ; $\mathrm{p}=0.008)$

There was no positive and statistically insignificant relationship with nutritional status between maternal age $(\mathrm{OR}=1.02$;
95\% $\mathrm{CI}=0.48$ to $2.18 ; \mathrm{p}=0.946)$, maternal occupation $(\mathrm{OR}=1.21 ; 95 \% \mathrm{CI}=0.46$ to 3.16; $\mathrm{p}=0.691)$, and maternal gender $(\mathrm{OR}=$ $0.86 ; 95 \% \mathrm{CI}=0.43$ to $1.72 ; \mathrm{p}=0.676)$.

\section{DISCUSSION}

\section{Clean and healthy behavior and} child nutritional status

This study found a positive relationship between healthy hygiene behavior and the nutritional status of children under five, and it was statistically significant. Children under five from mothers who had good clean and healthy behavior had a 5.50 times probability of good nutritional status compared to poor clean and healthy behavior.

The results of this study were in accordance with Uliyanti (2017) that low or poor hygiene and healthy living behavior can increase the risk of stunting in toddlers in Matan Hilir Selatan District, which was 6.67 times greater than families who had good clean, and healthy behavior. The results of this study explained that clean and healthy behavior had a significant effect on nutritional status, height according to age, high and low clean and healthy behavior had an effect on nutritional status. The higher the clean and healthy behavior, the better the nutritional status. 
The results of this study found that good household cleanliness and healthy behavior were $96 \%$. The data showed that clean and healthy behavior in the Waingapu Health Center is relatively good. This statement was based on data from observations of clean and healthy behavior, especially in terms of several indicators that had not met, namely exclusive breastfeeding, weighing infants and toddlers every month, using clean water, availability of healthy latrines, consumption of fruits and vegetables, smoking behavior in the house.

Environmental sanitation is closely related to the availability of clean water, the availability of latrines, the type of floor of the house, and the cleanliness of eating utensils in each family. The more available clean water for daily needs, the smaller the risk of children suffering from malnutrition. Infectious diseases cause nutrient metabolism in the body to be disturbed to cause malnutrition (Katona, 2008).

Clean and healthy living behavior is related to maintaining and improving health status and prevention of infectious diseases, including personal hygiene, selection of healthy and nutritious food, environmental cleanliness, use of clean water that meets health requirements, and use of healthy latrines not smoking in the house. The low nutritional status is caused by several interrelated factors: food availability at the household level, environmental health, economic status, and infectious diseases. Clean and healthy living behavior is another factor that affects the nutritional status of toddlers (Depkes, 2008).

The meta-analysis results showed that the WASH (water, sanitation, and hygiene) intervention was significantly associated with an increase in nutritional status (WAZ) in children under five. One of the interventions carried out was to promote washing hands after defecation or before touching food. Water sanitation and poor hygiene are associated with malnutrition in children due to diarrhea, infections, and intestinal worms. This study explains that effective water, sanitation, and hygiene interventions can improve nutritional status in toddlers (Gizaw, 2019).

Based on the existing problems, low clean and healthy behavior in the Working Area of the Waingapu City Health Center, the intervention that can be carried out is training for health promotion officers on counseling effective methods and forming clean and healthy behavior cadres as an extension of the officer's hand to increase households with good clean and healthy behavior. These two intervention efforts are interrelated. Training for health workers and forming cadres aims to increase innovation in conducting effective counseling so that households with good and correct clean and healthy behavior can be achieved (Fannya, 2020).

\section{Social capital and nutritional status of children under five}

This study found a positive relationship between social capital and the nutritional status of children under five, and it was statistically significant. Children under five from mothers with high social capital have a 2.28 times probability of having good nutritional status than mothers with low social capital.

The results of this study are in accordance with the findings in Laguna, Philippines. This study showed a relationship between maternal social capital and the nutritional status of children aged 6 to 24 months. High maternal social capital will improve children's nutritional status, and low maternal social capital was significantly associated with poor nutritional status (Domingo, 2017).

The results of this study were in accordance with the findings in Sragen 
Regency. This study showed a significant relationship between the nutritional status of children under five with social capital. Families who live in high social capital environments tend to have a better nutriational status of children under five than those who live in low social capital environments (Trimanto, 2008).

Social capital was related to health and health behavior. Social capital characterizes the relationships and interactions between individuals and groups. Social capital affects health through several mechanisms, namely norms and attitudes that influence health behavior and psychosocial networks that increase healthcare access (Tarja, 2013). High social capital makes it easier for community members to share health information, access, and better use the community resources to improve public health status (Bolin, 2003).

Based on observations in the social capital field in Waingapu City, it has involved elements in the community, from ordinary people, community leaders, religious shops, Family Welfare Development groups, and others. The involvement of community members in the village in various activities occurs without any coercion. This was manifested by traditions still carried out today, such as the gotongroyong tradition, the mourning tradition, and gathering hands. In Indonesia, with the existence of social relations in mutual assistance, a sense of kinship, and a high sense of togetherness, it is possible to develop social capital. Assistance is provided by the local community and support from the social environment to support child nutritional status (Runingsari, 2014).

Based on observations in the field, the existence of various formal and informal institutions in the community positively impacts the village's success, being more advanced in various fields, including in the health sector. Positive impacts in the health sector, such as ambulance groups from formal organizations, are used as joint accountants used by community members in need. Participation and cooperation in community groups create reciprocal relationships between groups to have equal access to their health resources. The results of this study were in accordance with the theory that social capital can affect health (Kawachi, 2001). The existence of social capital through social networks and communities impacts the quality of health protection (Yuasa, 2007).

Social capital referred to social relationships and connections between individuals because it is more of a relationship between individuals than an individual attribute. The key concept here is that social capital is not an individual characteristic or personality trait but a resource that lies within networks and groups of people. These resources are useful for health production if utilized (Murti, 2009).

\section{AUTHOR CONTRIBUTION}

Stevani Rambu Kudu was the main researcher who selects the topic, searches and collects research data. Yulia Lanti Retno Dewi and Setyo Sri Raharjo analyzed data and reviewed research documents.

\section{FUNDING AND SPONSORSHIP}

This study was self-funded.

\section{CONFLICT OF INTEREST}

There was no conflict of interest in this study.

\section{ACKNOWLEDGMENT}

We are very grateful to the Waingapu City Health Center, which permitted the research. 
Kudu et al./ Clean and Healthy Behavior, Social Capital, and Nutritional Status

\section{REFERENCES}

Bolin K, Lindgren B, Lindstrom M, Nystedt $P$ (2003). Investments in social capital-Implications of Social Interactions for The Production of Health. Soc Sci Med. 56(12): 2379-2390. Doi: 10.1016/So277-9536(02)00242-3.

Depertemen Kesehatan (2008). Pedoman Pengolahan dan Penyajian Informasi Perilaku Hdup Bersih Dan Sehat (Guidelines for Processing and Presentation of Clean and Healthy Life Behavior Information). Pusat Promosi Kesehatan. Jakarta

Dinas Kesehatan Sumba Timur (2020). Data Balita Underweight Hasil ePPGBM Kabupaten Sumba Timur Periode Agustus 2020. Waingapu

Domingo GC, Vc Barba C, Theresa M, Talavera $M$, Tolentino $L$, Naupal-Forcadilla R, Los B (2017). Association of maternal social capital with nutritional status of 6 to 24-month-old children association of maternal social capital with nutritional status of 6 to 24-month-old children living in urban and rural areas in Laguna, Philippines. 23(1): 53-63. https://nutriweb.org.my/mjn/publication/23-1/f.pdf.

Fannya P, Laela I (2020). Pemecahan masalah rendahnya cakupan PHBS di wilayah kerja Dinas Kesehatan Kota Payakumbuh (Troubleshooting the low coverage of PHBS in the work area of the Payakumbuh City Health Office). Indones Health Information Manage J. 8(5): 21-28

Gizaw Z, Worku A (2019). Effects of single and combined water, sanitation and hygiene (WASH) interventions on nutritional status of children: A systematic review and meta-analysis. Riv Ital Pediat. 45(1):1-14. https://doi.org/10.1186/s13052-019-0666-2
Hidayat Y, Asirin, Sumarni (2010). Analisis faktor-faktor yang mempengaruhi kejadian gizi buruk pada balita di Kabupaten Kebumen Tahun 2010 (Analysis of factors affecting the incidence of malnutrition in toddlers in Kebumen Regency in 2010). Jurnal Publikasi Kebidanan Akbid YLPP Purwokerto. 2(2): 1-10

Hidayat T, Fuada N (2011). Hubungan sanitasi lingkungan, morbiditas dan status gizi balita di Indonesia (Relationship of environmental sanitation, morbidity and nutritional status of toddlers in Indonesia). J Nutr Food Res. 34(02): 104-113.

Kawachi I, Berkman LF (2001). Social ties and mental health. J Urban Health. 78(3): 458-467. Doi: 10.1093/jurban$/ 78.3 .458$

Katona P, Katona J (2008). The interaction between nutrition and infection. Clin Infect Dis. 46(10): 1582-1588. https://doi.org/10.1086/587658.

Kementrian Kesehatan RI (2016). Gerakan PHBS sebagai langkah awal menuju peningkatan kualitas kesehatan masyarakat (PHBS movement as the first step towards improving the quality of public health). Https://Promkes.Kemkes.Go.Id/Phbs. Diakses 02 Desember 2020.

Murthi B (2009). Determinan sosio-ekonomi, modal sosial dan implikasinya bagi kesehatan masyarakat (Socioeconomic determinants, social capital and its implications for public health). Pidato Pengukuhan Jabatan Guru Besar Ilmu Kesehatan Masyarakat. Surakarta: Universitas Sebelas Maret.

Putnam R (2000). The collapse and revival of America community, New York; Social capital: J Urban Aff. Accessed Desember 2020. Http://Www.Bowlingalone.Com/Media.Php3. 
Kudu et al./ Clean and Healthy Behavior, Social Capital, and Nutritional Status

Riskesdas (2018). Hasil Utama Riskesdas 2018. Kementrian Kesehatan RI: Badan Penelitian Dan Pengembangan Kesehatan.

Runingsari $\mathrm{T}$ (2014). Kontribusi unsur social support dalam mendukung social support (Contribution of social support elements in supporting social support). Skripsi. Semarang: Universitas Negeri Semarang.

Supraptini, Hapsari D (2011). Status gizi balita berdasarkan kondisi lingkungan dan status ekonomi (Data Riskesdas 2007) (Nutritional status of toddlers based on environmental conditions and economic status (Data Riskesdas 2007)). Jurnal Ekologi Kesehatan. 2(2): 103-113

Tarja (2013). Social capital, health behaviours and health: a population-based associational study. BMC Public Health. 13: 613. doi:10.1186/1471-2458-13-613.

Trimanto (2008). Hubungan antar tingkat pendidikan ibu pendapatan keluarga dan modal sosial dengan status gizi anak balita di Kabupaten Sragen (The relationship between mother's education level, family income and social capital with nutritional status of toddler children in Sragen Regency). Tesis. Surakarta: Universitas Sebelas Maret
Unicef (2020). Situasi Anak Indonesia (Indonesian Children's Situation). Jakarta : Unicef Indonesia

Unicef (2019). The State Of The World's Children . Unicef For Every Child

Ulyanti 2017. Hubungan pengetahuan gizi ibu, asupan, gizi, riwayat penyakit infeksi, perilaku hidup bersih dengan kejadian stunting pada anak usia 2459 bulan di wilayah Pesisir Pantai Kecamatan Matan Hilir Selatan Kabupaten Ketapang (The relationship of maternal nutrition knowledge, intake, nutrition, history of infectious diseases, clean living behavior with stunting incidence in children aged 24-59 months in the coastal area, South Matan Hilir District, Ketapang Regency). Tesis. Surakarta: Universitas Sebelas Maret.

WHO (2013). World Health Stactistic 2013. Https://Www.Who.Int/Gho/Publications/World_Health_Statistics/EnW hs2013_Full.Pdf Accessed November 2020.

Yuasa M, De Sá RF, Pincovsky S, Shimanouchi N (2007). Emergence Model of social and human capital and its application to the Healthy Municipalities project in Northeast Brazil. Health Promotion Int, 22(4): 292298. https://doi.org/10.1093/heapro/damo2. 